\title{
Legal resistance to sex robots
}

\author{
Gary E. Marchant*,** and Kyra Climbingbear** \\ Arizona State University, USA
}

\begin{abstract}
This article explores the dynamic and the implications for the legal response to sex robots, using the United States legal system as a case study. This article does not try to cover all legal aspects of sex with robots, but rather focuses on likely legal strategies to prohibit or restrict sex robots. The American legal system has traditionally followed a twostep approach to non-traditional sexual practices, typified by an initial effort to prohibit such practices to protect "public morality," followed by a subsequent period of relaxation and non-enforcement. This pattern will likely apply to sex robots, where some state legislatures will likely seek to ban sex robots outright, but may encounter Constitutional obstacles and the unwillingness of law enforcement to expend significant resources enforcing against such "victimless crimes." More focused prohibitions that go beyond public morality arguments and seek to protect arguably legitimate interests will have greater salience. Examples include prohibitions on child sex robots that may be used to promote pedophilia, the recognition of human-robot marriage that could weaken the unique human bonds that sanctify marriage, and sex robot brothels that could debase and damage neighborhoods. However, even these more legitimate goals in restricting certain applications of sex robots are likely to encounter legal obstacles under U.S. constitutional law, and thus likely follow the two-step dynamic seen for other non-traditional sexual practices of initial attempts at legal prohibition followed by relaxation of enforcement and implicit acceptance.
\end{abstract}

Keywords: Sex robots, constitutional law, First Amendment, public morality, obscenity, marriage, prostitution, pedophilia

\section{INTRODUCTION}

The relationship between sex and the law is long and complex, but this historical interaction can help predict the likely legal response to sex robots. The interaction of sex and law exists at two levels - the formal level at which laws are enacted, and the more practical level at which laws are implemented and enforced (Posner, 1992). The enactment of laws relating to sexual matters tends to be highly symbolic, reflecting a reactionary aversion in many societies to any alternative or deviant sexual practices. This puritanical posture towards anything sexual outside of traditional heterosexual marital sex for procreation purposes is rhetorically popular and politically compelled in most jurisdictions, yet does not reflect the reality "on the ground" of what citizens actually believe and practice. In their daily lives, many if not most citizens are very interested and tempted by alternative sexual practices, and frequently engage in private actions or support sexual liberty norms that contradict the prudish public posture and laws they claim to support (Posner, 1992; Kaplan, 2014).

This complex and internally inconsistent Law-Sex dynamic will be important in understanding and predicting the legal response to sex robots. The projected widespread commercialization and availability of sex robots will trigger the typical reactionary public and political response to novel sexual practices that will lead to proposals to legally restrict sex robots in whole or in part. These restrictions may be on the general sale and promotion of sex robots, or on more specific aspects such as sale of

\footnotetext{
*Corresponding author. E-mail: gary.marchant@asu.edu; Tel.: 480-965-3246.

${ }^{* *}$ Center for Law, Science \& Innovation, Sandra Day O’Connor College of Law, Arizona State University, Phoenix AZ, USA

2589-9953 ( 2022 - The authors. Published by IOS Press. This is an Open Access article distributed under the terms of the Creative Commons Attribution-NonCommercial License (CC BY-NC 4.0).
} 
minor sex dolls, marriage to sex robots, and sex robot prostitution and brothels. Based on the historical dynamic summarized above, we can expect a highly puritanical symbolic legal restriction of sex robots in these contexts initially followed by a much more relaxed and accepting public and legal acceptance over time.

This article explores this dynamic and the implications for the legal response to sex robots, using the United States legal system as a case study. This article does not try to cover all legal aspects of sex with robots, but rather focuses on likely legal strategies to prohibit or restrict sex robots according to the two-step dynamic described above. As such it does not address other potential important legal issues such as privacy, safety, adultery, appropriation of likeness, consent, or possible claims for rape or violence against robots. This analysis assumes that sex robots are not sentient and have no legal rights or moral standing, which is certainly the case today, but if this should change in the future, the legal analysis that follows may be substantially altered.

Part I further develops the theme of the two-step dynamic in legal proscriptions of non-traditional sexual practices, where public postures are very restrictive but private beliefs are more permissive. Part II then applies this dynamic to sex robots. It first explores potential outright bans on sex robots in some states based on moral outrage, an action that is odds with growing legal and political concepts of sexual liberty. Part III then examines more narrow and applied restrictions on sex robots, focusing on three examples of child sex robots, marriage with sex robots, and sex robot prostitution and brothels. These applications of sex robots will provoke more legitimate and instrumental concerns beyond general moral outrage, such as the public desire to, respectively, prevent pedophilia, maintain the sanctity of marriage as a bond between two human beings, and preserve the order and decency of neighborhoods in which families live and other businesses operate. Notwithstanding these reasonable public goals, attempts to restrict such applications of sex robots may face legal vulnerabilities consistent with the two-step dynamic elaborated in the next section.

\section{THE REACTIONARY SYMBOLIC LEGAL RESPONSE TO NON-TRADITIONAL SEXUALITY}

American law has historically taken a restrictive approach to any alternative or deviant sexual practices in its enacted statutes and judicial decisions, which "is a residue of the nation's puritan - more broadly of its Christian - heritage." (Posner, 1992, p. 1). At the same time, it has tempered that moral absolutism in implementation by often not enforcing the strict legal standards, or gradually relaxing those standards over time (Posner, 1992).

The U.S. legal system has traditionally treated sexuality and sexual pleasure as a destructive element or negative force, something to be tempered and restricted (Wodda \& Panfil, 2018). Despite evidence showing that sexual pleasure is an important source of happiness and personal fulfillment, the law assumes "just the opposite - that sexual pleasure in itself has negligible value and we sacrifice nothing of importance when our laws circumscribe it" (Kaplan, 2014, p. 90). This presumptive negativity against sex and sexual pleasure is "baked" into our statutes, case law and legal commentary, often going unquestioned (Kaplan, 2014).

This "sex negativity" has been expressed in a number of contexts over the years, including criminalization of sex outside of marriage, mixed race and same sex relationships, sodomy, sex among minors, sex in public, public nudity, group sex, polyamory, sex work, commercial sex, sex using pornography or sex toys, online sex, and sadomasochistic sex (Wodda \& Panfil, 2018). The only sex that is sanctioned is "good, normal, natural, blessed sexuality" that consists of private acts between two married, heterosexual, monogamous individuals from the same generation that engage primarily in procreative 
and penetrative sex using only their bodies and no other tools or fantasy-generating images (Rubin, 2011; Wodda \& Panfil, 2018).

The legal antipathy to sexuality and sexual pleasure is rooted in the objective of protecting "public morality." This legal crusade to protect alleged public morality is seen through the imposition, application and enforcement of obscenity laws. The U.S. Supreme Court held in 1973 in Miller v. California (1973, pp. 23-26) that states could restrict "obscene materials" if they, "taken as a whole, appeal to the prurient interest in sex,... portray sexual conduct in a patently offensive way, and .... do not have serious literary, artistic, political or scientific value." By allowing the banning of materials that "appeal to the prurient interest in sex" the Court characterized an interest in sex, one of the most basic human needs and sources of human pleasure as well as continuation of our species, as something that is bad and offensive. A "prurient interest" has been defined by the Supreme Court as "to excite lustful thoughts, a shameful or morbid interest in sex or nudity, arouse sexual desires or sexually impure thoughts" (Roth v. United States, 1957). Moreover, there is seen to be no positive value in promoting sexual pleasure in and of itself, with only those rare materials that have "serious literary, artistic, political or scientific value" worthy of protection. As Margo Kaplan has argued, "[v]aluing sexual pleasure for its own sake undermines the morality-based arguments for limiting sexual activity...." (Kaplan, 2014, p. 94).

The lack of First Amendment protection for sexually-oriented material is peculiar given the more fundamental First Amendment principle announced in Brandenburg v. Ohio (1969) that states are prohibited from banning speech unless they can demonstrate that harm is both imminent and extremely likely to occur as a result of that speech. Some scholars have argued that some forms of obscenity may be harmful, for example by degrading women or potentially subjecting them to violence (Sunstein, 1986). That may be true for some types of materials that fall within the definition of obscenity, but it does not apply to all materials appealing to the prurient interest in sex, so the legal definition of obscenity does not fit these harms (Kaplan, 2014). Moreover, the courts have not made the necessary finding of harm for such materials to ban them under the Brandenburg framing of the First Amendment.

Rather, what we have here is a mindset that sex is different. Sexual content is the one and only type of material that can apparently be banned without showing any harm (Kaplan, 2014). This sexual exceptionalism under the First Amendment reflects the powerful assumption in the law of the United States that sex not only has no value, but that it is something bad and corrosive that must be suppressed and constrained. In other words, "[i]t is the perceived moral harm inherent in sexual pleasure - and in particular deviant sexual pleasure - that is obscenity law's concern" (Kaplan, 2014, p. 110).

The U.S. courts have, in decision after decision, held that their self-perceived role is as moral enforcer to protect society against the harmful effects of non-traditional sexual activity. For example, in a case upholding the criminalization of nude exposure in public, the Supreme Court stated it is the legal system's duty to protect "societal decency and morality" (Barnes v. Glen Theatre, Inc., 1991). In Bowers v. Hardwick (1986), the Supreme Court held, in a decision that was later reversed (see below), that states could criminalize homosexual acts between consenting adults in their private home given the historical role of states in enforcing expressions of public morality. In another case upholding the state's termination of a police officer for practicing polygamy, a federal court of appeals held that the legal system has "a compelling interest in protecting the monogamous marriage relationship" because "[m]onogamy is inextricably woven into the fabric of our society... [and] is the bedrock upon which our culture is built" (Potter v. Murray City, 1985).

Perhaps the sex-related decisions having the most relevance to sex robots are judicial decisions on the legality of state laws prohibiting sexual pleasure devices such as vibrators and artificial vaginas. 
While some state courts have found such bans on sex toys to be unconstitutional (Reliable Consultants, Inc. v. Earle, 2008), other cases have upheld some prohibitions as consistent with the court's role in upholding public morality (Williams v. Morgan, 2007). States that continue to ban sex toys defend their laws based in their state interest in discouraging "prurient interests in autonomous sex" and the "pursuit of sexual gratification unrelated to procreation." (Kaplan, 2014, p. 157).

Notwithstanding this initial hostility to any non-traditional sexual practice, American jurisprudence has exhibited a pattern of ultimately moving away from such initial restrictions by either relaxing such prohibitions or declining to enforce them. Thus, even though the U.S. Congress and state legislatures often seek to criminalize any non-traditional sexual practices, these puritanical legislative efforts are often over-turned or constrained (e.g., "taking the sting out of sexually restrictive legislation by interpretation") by the courts that serve as "a buffer between legislatures and the citizenry" (Posner, 1992, p. 78). For example, consider the following three landmark U.S. Supreme Court decisions relaxing previous restrictions on non-traditional sexual practices:

Loving v. Virginia (1967): Even though 16 States still classified interracial marriages as a crime as of 1967, the Supreme Court ruled that the "anti-miscegenation" statute of Virginia, and hence similar laws in other states, violated the Equal Protection Clause and Due Process Clause of the $14^{\text {th }}$ Amendment by restricting the freedom to marry due to racial classification. The court stated that "to deny this fundamental freedom on so unsupportable a basis... is surely to deprive all the states citizens of liberty without due process of law."

Lawrence v. Texas (2003): Over-turning its previous decision in Bowers v. Hardwick (1986), the Supreme Court struck down a state statute criminalizing intimate sexual conduct by people of the same sex. The Court identified sexual conduct and intimacy as "the most private human conduct" and held that "[1]iberty presumes an autonomy of self that includes freedom of thought, belief, expression, and certain intimate conduct" (p. 567). The Court nevertheless made clear that the right to sexual liberty is not without limits, and noted that sexual acts involving injury, minors, coercion, prostitution, or conduct in a public place were not legally protected (p. 578). Three Justices joined a dissenting opinion written by Justice Scalia, warning that the rejection of moralistic arguments against same sex relations would jeopardize prohibitions on incest, masturbation, adultery, fornication, prostitution, and bestiality (p. 590).

Obergefell v. Hodges (2015): The Supreme Court over-turned state bans on same-sex marriage, holding the right to such a marriage was a fundamental right. The Court stated that "[n]o union is more profound than marriage, for it embodies the highest ideals of love, fidelity, devotion, sacrifice, and family ... [The petitioners] hope is not to be condemned to live in loneliness." Yet, as the Court noted, the institution of marriage had changed over the years. Marriage once involved arranged matches made by parents on behalf of their children for political, religious, and financial ends, and marriage used to result in the husband subsuming the legal rights of the wife through the doctrine of coverture. Over time, women gained more equality in the marital arrangement as women's rights gained greater recognition in society, which the Court saw as parallel to the more recent recognition of gay and lesbian rights in the $20^{\text {th }}$ century.

These three Supreme Court decisions are notable because they involve the Supreme Court for the first time rejecting state arguments for public morality in restricting people's sexual and marital liberty. In these three decisions, individual sexual rights and freedoms over-rode the state's claim for promoting public morality. Yet, notwithstanding these decisions, morality remains a potent force used by state governments and courts in deciding the legality of various non-traditional sexual activities outside the specific activities protected by these three decisions (Goldberg, 2004). 
In addition to expressly overturning or rescinding laws or court decisions that suppress sexual activity, the legal system can also relax its anti-sexual agenda by declining to enforce sex- negative laws on the books. Indeed, over the years, the law often turned a blind eye in the majority of cases to not enforce against expressly illegal sexual activities such as adultery, homosexuality, nudity and obscenity. As summarized by Judge Richard Posner, "[i]t is well known that laws punishing socially disfavored sexual behavior, with the partial exception of those regulating coercive sex, such as rape and the seduction of young children, are rarely enforced with even minimum effectiveness. Mostly they are dead letters, yet efforts to repeal them are resisted vigorously" (Posner, 1992, p. 4). However, keeping such "radically unenforced" laws on the books is not without effect (Posner, 1992) - as the Supreme Court noted in Lawrence, laws that are enforced much less than they are violated are not trivial; such laws publicly condemn the activity, stigmatize the practice and the individuals engaging in it, and subject those individuals to public shame (Lawrence v. Texas, 2003, p. 575).

To conclude, federal and state legislatures in the United States will often jump to adopt laws to restrict non-traditional sexual practices, especially when such practices become newsworthy or novel, pandering to the prurient streak in American public discourse. However, especially when such laws involve "victimless" crimes involving consensual practices between adults, these laws will tend to be weakened or eliminated over time, either by being expressly over-turned or more often by withering into insignificance by lack of meaningful enforcement.

\section{PROSPECTS FOR GENERAL BANS ON SEX ROBOTS}

Given the history of the legal system responding negatively initially to any non- traditional sexual activity, followed by an easing off that includes legal reversals and non-enforcement, sex robots are likely to encounter a similar rocky legal reception in the United States as they move toward broader commercialization and use. The most drastic response of some states might be an outright ban on sex robots. For example, Simmons (2016) advocates preemptive moral legislation to ban sex robots outright.

It is likely that some states will attempt to ban sex robots outright, in the same way that some states still ban sex toys. For example, Alabama's Anti-Obscenity Enforcement Act of 1998 prohibits the sale of "any device designed or marketed as useful for the stimulation of human genital organs." This legislation was upheld by the Eleventh Circuit under the U.S. Constitution in 2004 (Williams v. Att'y Gen. of Ala., 2004) and by the Alabama Supreme Court in 2010 under state law (1568 Montgomery Highway v. City of Hoover, 2010), and remains valid law to this day. The courts upheld this statute based on the state's interest in protecting "public morality." Such a prohibition in its current language or with slight modifications would arguably already extend to a sex robot. However, Alabama police currently enforce the Alabama anti-sex toy law very sporadically and rarely, and if the same applied to sex robots, there again would be a difference between the public legal puritanical posturing and the much more accommodating of sexual activities in on-the-ground reality.

The U.S. courts are not unanimous, however, in upholding the constitutionality of bans on sex toys, and perhaps by extension of sex robots. For example, the Fifth Circuit held that Texas's prohibition of the sale of sex toys was prohibited under the right of private sexual liberty established in Lawrence (Reliable Consultants, Inc. v. Earle, 2008). The court held that "controlling what people do in the privacy of their own homes because the State is morally opposed to a certain type of consensual private intimate contact" violates the U.S. Constitution (p. 746). Unless the Supreme Court steps in to ensure national legal uniformity, bans on sex robots will likely be limited to more conservative states, just like existing bans on sex toys. 
As is the case with sex toy prohibitions, laws attempting to ban sex robots will likely focus on the commercial sale and promotion of such devices, rather than private ownership in the home. The Supreme Court held in Stanley v. Georgia (1969) that criminalizing the possession of obscene materials in the privacy of citizen's homes is a violation of the First and Fourteenth Amendments. A unanimous Supreme Court stated that the constitution "rebels at the thought of giving government the power to control men's minds." Yet, the Court did allow states to prohibit the sale and promotion of those same materials, and a similar differentiation is likely to apply for sex robots. Of course, it is difficult to own a sex robot if the sale of such items is prohibited, but such arguments have sometimes failed in the context of bans on the promotion or sale of sexual devices (Williams v. Att'y Gen. of Ala., 2004).

As with many other non-traditional sex-related issues, attacks against non-traditional sex practices and technologies tend to be good politics, especially in conservative southern states. State legislators are therefore likely to grandstand in their purported role as protectors of public morality in opposing sex robots. Legislators would likely find support from an ad hoc coalition of stakeholders that includes conservative religious groups concerned about the effect of sex robots on public morality, and more progressive opponents concerned about the potential impact of sex robots on the objectification and exploitation of sex and women (Richardson, 2016; Danaher et al., 2017; Devlin, 2018). An example of the latter voice is the Campaign Against Sex Robots in the U.K., which has recently been renamed the Campaign Against Porn Robots (Campaign Against Porn Robots, undated).

While legislative efforts to prohibit sex robots are likely and may succeed in some states, the impact of these proposed bans is likely to be limited. First, as we have seen with sex toys, most states no longer attempt to ban such devices and now permit the sale of such devices as a matter of consumer choice and freedom, and many states are likewise likely to refrain from restricting sex robots for similar reasons. Arguments on behalf of many seniors, the physically and mentally disabled, and others unable to engage in traditional human-human sexual relations to allow them to use sex robots to achieve the important benefits of sexual activity will carry weight in more progressive states (Levy, 2007; Jecker, 2021). A more practical argument is that as robots assume a greater role and presence in our lives generally, it is likely that such robots will be built for multiple purposes including housecleaning, companionship and sex (Danaher, 2017b; Kleeman, 2020), making it difficult to draw an enforceable line on when a multi-functional household robot becomes a "sex robot" (Shen, 2019).

In conclusion, while some states may attempt to legally ban the sale and promotion of sex robots, many states likely will not, and no state may prohibit the private ownership or use of a sex robot at home. States that ban the sale of sex robots will likely gradually stop enforcing such a ban once the novelty and public sensationalism with such technology fades.

\section{MORE NARROW LEGAL RESTRICTIONS ON SEX ROBOTS}

While general bans on sex robots are likely to be attempted, and in a few cases may succeed, they are unlikely to have much practical effect in restricting sexual robot availability in the long run because of the weak justification for restricting consenting adults' sexual liberty based on public morality. The history of repression of non-traditional sexual practices discussed above suggests that public morality alone is unlikely to provide a sustainable rationale for restricting the sexual freedom of consenting adults in their own homes. However, some more narrow restrictions of certain sex robot uses or activities may succeed in attracting greater political and legal support if they serve to advance stronger and more legitimate goals. Three such examples are bans on child sex robots, refusal to recognize marriage to sex robots, and restrictions on sex robot prostitution and brothels. As compelling as these 
restrictions may be on public policy and public opinion grounds, they each also suffer from legal vulnerabilities.

\section{BANS ON CHILD SEX ROBOTS}

In contrast to the unlikelihood of national bans on sex robots generally, there is greater likelihood that childlike sex robots will be banned at the national or state level, but the legal validity of such bans is uncertain and debatable. Child-like sex dolls are currently being manufactured in Asian countries such as China and Japan and exported to western countries (Cox, 2018). These anatomically correct dolls are life-size reproductions of young or prepubescent children with sexual organs for their intended age and are intended for sexual intimacy and intercourse (Maras and Shapiro, 2017). These products are being improved from dolls to robots using artificial intelligence and other technologies to provide an even more realistic portrayal of a living human child. These enhancements allow the child robot to actively engage with their user, including performing sexual acts, and displaying emotions such as pleasure, fear, and sadness (Cox, 2018). Not surprisingly, these products are generally perceived as enabling or simulating pedophilia and are viewed with disgust by an overwhelming majority of the population.

In 2017, over 100 of these dolls were seized by officials in the UK, and 85 percent of the men who had imported the dolls were also found to have child pornography in their possession (Felton, 2018). In the UK, possession of a child sex robot is not illegal, but importing them is, so law enforcement focuses on the importation step. The 1979 U.K. Customs and Excise Management Act bans the importation of "indecent or obscene articles," which the courts have concluded includes "anatomically detailed" childlike sex dolls, and thus the UK has criminally convicted individuals attempting to import such products (Dearden, 2017). In one case where the defendant's attorney argued that childlike sex dolls were not obscene, the judge rejected that argument and stated that "any-right thinking person" would have found the doll obscene (Lui, 2017). Several other countries have banned childlike sex dolls outright or have enacted laws restricting their sale and use (Cox, 2018). However, it is important to recognize that other countries do not have the equivalent of the First Amendment in the United States.

In the United States, it is possible that authorities could try to seize child-sex robot shipments as obscene materials. Section 1305 of Title 19 of the U.S. Code, adopted as part of the Tariff Act of 1930, gives the U.S. Customs Office the authority to seize items that are "obscene or immoral," and refer the matter to the District Attorney for criminal prosecution. Section 1462 of Title 18 makes the importation of obscene or immoral materials a criminal offense subject to fines and/or imprisonment of up to five years for the first offense. So while U.S. authorities may have the power to block the importation of childlike sex dolls if they are deemed to be obscene, assuming they can detect them when shipped to the U.S., there is currently no express law against purchasing, owning or using childlike sex robots.

In 2018, the U.S. House of Representatives tried to change that by unanimously passing the Curbing Realistic Exploitative Electronics Pedophilic Robots (CREEPER) Act, which would ban child sex robots in the United States based on broad but contested claims that these robots are intrinsically linked to the sexual abuse of minors. While the CREEPER Act unanimously passed in the House in 2018, it died in the Senate.

In the subsequent Congress, a House committee introduced the Jurists United to Stop Trafficking Imitation Child Exploitation Act of 2019 ("JUSTICE Act") that included many of the same provisions of the CREEPER Act. This bill was not voted on by the House or Senate. Both proposed statutes have 
been criticized for ambiguity and unsupported assertions. For example, the JUSTICE Act defines child sex dolls, the sale or transport of which would be banned under the statute, as dolls "with the features of, or with features that resemble those of, a minor." This vague language may ensnare individuals that do not intend to sell a child sex robot but rather a more petite or non-minor younger sex robot. While such behavior may be morally repulsive, it likely would be unconstitutional to legally ban since the sex robot could arguably be resembling a person of legal age. Moreover, one of the findings in the legislation was that child sex dolls and robots are "intrinsically related to abuse of minors, and they cause the exploitation, objectification, abuse, and rape of minors." While this may be true, there is a paucity of relevant evidence for (or against) this assertion.

In the words of one legal analysis, the CREEPER Act is "plainly" unconstitutional, and the Congressional findings used to support the Act "are a jumble of unsubstantiated, misleading, and irrelevant claims" (Levy, 2018). Specifically, the arguments against the constitutionality of the CREEPER Act are that the dolls prohibited under the statute do not necessarily "depict. . sexual conduct" which would be required to come under the obscenity exception to the First Amendment. Moreover, the statute does not provide exceptions for dolls which might have serious "literary, artistic, political, or scientific value," which again would be required for the obscenity exception to apply. Finally, the Congressional Findings supporting the bill claim that child sex robots will result in the rape of children, but cites no evidence for that assertion, and in the view of critics of the statute, "the jury is still out on the effect that access to child sex robots has on offenses against children" (Levy, 2018).

Meanwhile at the state level, Florida (SB 160), Tennessee (SB 0659), and Kentucky (SB 102) all recently considered or passed legislation in their Senate and House that criminalizes the possession, importation, and distribution of sex dolls in those states (Gersen, 2019). The maximum prison sentence for this crime is five years. Of these three state bills, Tennessee is the only one to be signed by its state Governor. It has been in effect since July 1, 2019, and so far has not been challenged in court. While the proposed federal legislation would prohibit the sale and transport of child sex robots, the three state laws also ban the possession of child sex robots, which almost certainly would violate the Supreme Court's Stanley v. Georgia (1969) decision against restricting private sexual acts within the home.

If enacted, a U.S. or state ban on child sex robots may run afoul of the First Amendment. The Supreme Court, in Ashcroft v. Free Speech Coalition (2002), held that a law prohibiting computer-generated child pornography without using any real children was unconstitutionally overbroad. At issue was the Child Pornography Prevention Act of 1996 (CPPA), which expanded federal prohibitions against the possession and distribution of pornography involving children to also include "any visual depiction, including any photograph, film, video, picture, or computer or computer-generated image or picture ... [that] is, or appears to be, of a minor engaging in sexually explicit conduct." The U.S. Supreme Court, in a 6-3 decision, held that the causal connection between any such virtual images and actual child abuse to be "contingent and indirect" (p. 250). In other words, because the digitally fabricated depictions of children were not real children, the connection between the images and actual child abuse was too attenuated.

One year later, Congress passed the Prosecutorial Remedies and Other Tools to end the Exploitation of Children Today Act ("PROTECT Act") to make it illegal to produce, distribute, receive, or possess with intent to distribute obscene virtual representations of children engaging in sexual acts (Maras \& Shapiro, 2017). Although prosecutors have used the PROTECT Act to bring several convictions to date, the statute suffers from the same legal vulnerabilities as the provisions of the CCPA held unconstitutional in Ashcroft, and unless there has been enough change in the Supreme Court membership 
to get a different result, the same outcome would likely apply in a case involving a virtual animated child.

The question thus becomes whether the same holding would apply to child sex robots. The purpose of a child sexbot is for the user to engage in sexual relations with a physical entity that would appear and behave just like an actual child. So the child sexbot involves a physical rather than virtual interaction between a child surrogate and the offender. In other words, a child sex robot is one step closer to the real thing than is an animated graphic, although neither involves real children (Strikwerda, 2017). The argument would then be that this pushes the abuser closer to actual abuse of a real child, and my increase the risk that the offender will take the next step and abuse a real child. The critical legal question of whether the child sex robot creates a direct enough linkage to abuse of a real child is therefore a close question that has not been addressed by a court.

The issue is further complicated by arguments that child sex robots could have a therapeutic or surrogate effect on sex offenders and reduce the risk of a real child being violated (Rutkin, 2016; Morin, 2016). Some community health organizations, medical doctors, and researchers have argued that childlike sex dolls have the potential to be used with pedophiles for treatment purposes (Dickson, 2014; Revesz, 2017). Others question that assertion. One theory is that pedophiles may become sated by their sexual interactions with child sex robots, and thus will be less inclined to abuse real children, while the opposing theory is that child sex robots will be a "gateway" or "stepping stone" that emboldens pedophiles to go one step further and seek "the real thing" (Maras \& Shapiro, 2017). Very little data actually exists to answer the question, and conducting the needed research would likely be unethical and problematic (Rutkin, 2016; Shen, 2019; Danaher, 2017a). With such a paucity of scientific evidence to support either of these conflicting arguments, it is difficult to project whether a court will conclude that a child sex robot presents an imminent and concrete risk to the safety of real children, as would be required for a ban under the Ashcroft test (Strikwerda, 2017).

Finally, even if a ban on child sex robots was permissible under the First Amendment, which is debatable, there would be more practical issues to overcome. For example, at what point does a sex robot become too childlike - many sex dolls are already sold with indicators they are supposed to be young girls. While the range of physiques possible across age ranges would create some grey zone for enforcement, there would be no ambiguity about the anatomically correct infant-like dolls currently being produced and sold. Another practical issue would be whether the ban applies to doll parts as well as whole dolls or robots? It is possible manufacturers could try to get around the ban by shipping the doll in separate parts that are then assembled by the end user, with each individual part being insufficient to violate a potential ban. Finally, it is probably just a matter of time until people could print a child sex robot on a home 3D printer, further circumventing any hope for blocking this technology using criminal law. (Chatterjee, 2017).

\section{HUMAN-SEX ROBOT MARRIAGE}

A second limited proscription of sex robots would be to continue to refuse to legally sanction humanrobot marriage. Even though no state legally recognizes human-robot marriages, there are already humans who want to and indeed unofficially do marry their sex dolls or robots. For example, in early December 2020, newspaper headlines screamed out that "Bodybuilder Marries Sex Doll After Two Years of "Dating"' (Elvin, 2020). Of course, the so-called "wedding" was not an official legallysanctioned wedding. But as the number of human-robot sexual and romantic relationships continue to grow in the coming years, there will be increasing requests and pressure for legal systems to recognize human-robot marriages (Levy, 2007). The recent U.S. Supreme Court decision in Obergefell 
v. Hodges (2015) expanding the scope of marriage to permit same-sex marriages provides the most relevant legal precedent that will likely be relied upon for expanding the legal right to marry to include human-robot weddings (Marchant, 2015; Osborne, 2020; Walter, 2020). While recognizing humanrobot marriage is obviously more controversial and not ethically equivalent to recognizing same sex marriage between two humans, there are already prominent proponents in favor of recognizing such a right to marry a robot (Moosa, 2014).

The Obergefell decision obviously lays the groundwork and pathway that would have to be satisfied for human-robot marriages to be legally sanctioned. The Supreme Court stated in that case that "the right to marry is a fundamental right inherent in the liberty of a person, and under the Due Process and Equal Protection Clauses of the Fourteenth Amendment couples of the same sex may not be deprived of that right and that liberty." In reaching its conclusion, the Court relied on "four principles and traditions" elucidating the role of marriage in society: (1) the significance of personal choice in marriage for individual autonomy, (2) the unique importance of the marital union to individual fulfillment, (3) the role of marriage in safeguarding family and children, and (4) the role of marriage in maintaining the social order. The Court in Obergefell found that all four "principles and traditions" weighed in favor of recognizing same-sex marriages.

Applying these four Obergefell factors to human-robot marriages, the first two factors would appear to favor human-robot marriages, whereas the last two weigh against (Marchant, 2015). The first factor is personal autonomy, and the Court held that " $[\mathrm{t}]$ he right to personal choice regarding marriage is inherent in the concept of individual autonomy.... Like choices concerning contraception, family relationships, procreation, and childrearing, all of which are protected by the Constitution, decisions concerning marriage are among the most intimate that an individual can make." Given that "[c]hoices about marriage shape an individual's destiny," the Court found that the principle of personal autonomy weighed in favor of recognizing same-sex couples" "autonomy to make such profound choices" as whether to marry. Given that millions of people go through life without being able to marry another human because of disability, looks, personality, or socio-economic status (Levy, 2007), it seems contrary to the principle of autonomy and self-fulfillment that such individuals should be denied the benefits and happiness provided by the institution of marriage solely because they are unable to marry fellow humans.

The second Obergefell factor also seems to weigh in favor of recognizing human-robot marriage. This second factor is the right to identify and define one's self within society by whom one chooses to marry. The Court found that marriage involves a freedom of intimate association that allows couples to "define themselves by their commitment to each other." Noting that "same-sex couples have the same right as opposite-sex couples to enjoy intimate association," the Court found this principle also weighed in favor of recognizing same-sex marriage. We are already seeing individuals coming forward who seek to publicly declare and define themselves as the married partner of a sex robot, and it seems consistent with Obergefell to allow those individuals to make the same public declaration of their love and commitment to a robot as any human-human couple.

The third and fourth Obergefell factors go more to the practical benefits of marriage, and provide weaker or no support for recognizing human-robot marriages. The third factor for protecting the right to marry is that it safeguards children and families and thus "draws meaning from related rights of childbearing, procreation, and education." Citing earlier decisions of the Court, the majority opinion in Obergefell explained that "marriage allows children to understand the integrity and closeness of their own family and its concord with other families in their community and in their daily lives. Marriage also affords the permanency and stability important to children's best interests." The Court noted that "[a]s all parties agree, many same-sex couples provide loving and nurturing homes to their children, 
whether biological or adopted," and that denying same-sex couples the right to marry effectively denies their children the material and psychological advantages of being raised by married parents.

Humans and robots will not have children together, so this benefit of recognizing human-robot marriages so that their children can feel part of an intact family group seems inapplicable, although it is conceivable that in the future a robot may perform parenting functions for a human partner's biological offspring. Same sex couples don't technically create babies with each other, even if they raise the children spawned from one or the other partner's gametes together. In the same way, the human participant in a robot-human marriage may choose to procreate with the help of another human, but plan to raise the children within the human-robot married family. So the relevance of this factor to human-robot marriage is equivocal or perhaps slightly negative.

Fourth, the Court considered the "[c] $]$ onstellation of benefits states have linked to marriage," including taxation relationships, inheritance and property rights, rules of intestate succession, spousal privilege in the law of evidence, hospital access, medical decisionmaking authority, adoption rights, the rights and benefits of survivors, birth and death certificates, professional ethics rules, campaign finance restrictions, workers' compensation benefits, health insurance, and child custody, support, and visitation rules. Since a robot spouse will rarely if ever benefit from such practical rights and responsibilities, nor will a robot confer such rights and responsibilities on a human relating to the robot's situation, this factor is the least relevant in supporting human-robot marriages. Moreover, human-robot marriage may create practical complications such as intestate inheritance of a robot spouse if the human spouse dies, or what happens to property and child custody in the event of a human-robot divorce (Ryznar, 2019). These practicalities weigh against giving legal effect to human-robot marriages.

So from a technical legal perspective, two of the four Obergefell factors seem to favor recognizing robot-human marriages, the third factor in neutral or slightly negative, and the fourth factor is negative. The Supreme Court found that all four factors favored same-sex marriage - would that also be required for recognizing human-robot marriage? Not necessarily. The first two factors may be more important than the last two. The first two Obergefell principles describe marriage as a profound expression of "personal choice," "individual autonomy," and the "freedom ... to engage in intimate association." These seem like fundamental principles of liberty and individual freedom. In contrast, the final two factors are more practical and administrative, and may not have the same gravamen as the first two. The last two factors do not result in bad things from human-robot marriage, they just don't provide the same legal and practical benefits that marriage between two humans does.

Moreover, the Obergefell opinion itself emphasizes that the third principle (enhancing family structure for children) is not even relevant for some marriages if they do not involve children. Yet, the court notes that the right to marry is not "less meaningful for those who do not or cannot have children" suggesting the third factor should be de-emphasized. Similarly, for factor four, the "constellation of benefits" associated with marriage include a variety of individual rights and responsibilities, none of which are imperative for a marriage to succeed, and many of which may not apply to some marriages. Again, this factor seems less essential to the institution of marriage than the first two factors, involving personal choice, individual expression, and commitment to another, which necessarily come into play in every marriage, whether between two humans or humans and robots.

As one of us has written previously, "[r]obot-human marriage is not about robot rights; it is the right of a human to marry a robot" (Marchant, 2015). In other words, it may not matter that the robot cannot share, love and commit to the marriage in ways that a human can, the benefits of marriage inure to the individual human spouse, and in this case it is only one human partner that receives those benefits, but they are no less important than in a normal bilateral human-human marriage. In fact, in the Obergefell case, the lead plaintiff James Obergefell was not joined by his partner in the lawsuit, because his 
partner, John Arthur, was dead. So James Obergefell was not fighting for the mutual benefit of the two partners, but rather he was fighting for his own right to be recognized by society as the lawful partner of his deceased and long-time lover, to do away with "a state-imposed separation Obergefell deemed 'hurtful for the rest of time."

Even if a straight-up legal argument based on the Obergefell precedent suggests that the stronger case is for recognizing human-robot marriage, despite some ambiguity and contradiction, that does not mean that human-robot marriage is a certainty or even a likelihood any time soon. The conservative, sex-negative public morality ethos of the law will push against recognizing human-robot marriage, just as it did for same sex marriage for many decades. Even the most ardent supporter of same sex marriage likely had doubts that they would see the legalization of same sex marriage in their lifetimes, as the wall against recognizing such unions seemed so tall and permanent. But then suddenly, eroded by the constant pushing, organizing and educating over many years by those who wanted the freedom to marry who they wanted for themselves and their loved ones, that wall quickly crumbled and gave way, opening the door for same sex marriage to finally be recognized. It will take much time and effort and changes in perception if human-robot marriage is ever legally sanctioned, but the lesson from Obergefell is that things change, sometimes much more quickly and dramatically than most expect.

In the context of analyzing the Obergefell decision, Yale law professor Jack Balkin described this dynamic by which concepts that were initially "off the wall" can become "on the wall" suddenly or gradually after many years of effort and organizing that did not seem at the time to getting traction but which in fact laid the groundwork for the rapid change that eventually occurred:

The history of American constitutional law has, in significant part, been the history of arguments that were once considered off the wall becoming on the wall and then being adopted by courts and becoming the new constitutional common sense. Sometimes this happens quickly; more often it happens over the course of many decades. But when it happens, lawyers who remember when these arguments were widely viewed as crazy may rub their eyes with disbelief - their legal world, which once seemed stable and intelligible to them, has been transformed before their eyes (Balkin, 2020, p. 7).

Just as the legal recognition of same-sex marriage once seemed off the wall but is now legally and socially accepted, the fact that human-robot marriage seems off the wall today does not mean it might not become accepted by law in the future.

Of course human-robot marriage is fundamentally different than human-human marriages, whether the latter be between two people of the same or different sexes. While the attempt to distinguish between male-female marriage and same sex marriage failed in both the political and legal arenas, there are real and salient differences between a marriage of two human beings and robot-human marriages. The reciprocal bond between two human beings is the value that marriage seeks to enhance and protect, and that bond is very different from the unidirectional bond between a human and machine. Perhaps one day robots will be capable of experiencing or expressing human emotions such as love, but until that day arrives, the argument for recognizing human-robot marriage will face an uphill political and legal battle.

\section{PROSTITUTION AND BROTHELS}

One model of sex robot implementation is that individual users will purchase a sex robot and interact with it in their private home (Bendel, 2021). However, sophisticated sex robots are likely to cost upwards of $\$ 10,000$ to $\$ 20,000$, which many potential users will be unable or unwilling to pay. An 
alternative and more affordable business model will be for sex robots to serve as prostitutes, mostly likely operating from brothels (Levy, 2007). Some scholars have predicted that sex robots will eventually displace most humans in the sex trade (Yeoman \& Mars, 2012). Indeed, some brothels in Europe and North America have already begun offering sex robot "prostitutes" at brothels for sexual services. For example, one of the first sex robot brothels opened in Barcelona in February of 2017 and it appears to be still operating (Lockett, 2017). Guests paid $\$ 125$ per hour and were able to choose between four different Lumidolls and even choose what the dolls wear. The dolls are disinfected with special antibacterial soaps before and after each service (Harper, 2017).

From an ethical and societal perspective, sex robot "prostitutes" are preferable to human prostitutes in many situations because they can reduce the problem of sex trafficking of young and involuntary participants in the sex trade. This is the worst aspect of prostitution, and could be significantly reduced with the rise of sex robot prostitutes. Sex robot prostitutes will also present less of a STD risk than human prostitutes, and may also reduce some of the safety risks and violence that human prostitutes frequently encounter. Conversely, the ethical and social downside of sex robot prostitutes is the displacement of livelihoods for adult sex workers.

From a legal perspective, while most jurisdictions make offering or soliciting prostitution services by a human a criminal act, that crime would likely not apply to a sex robot. Rather, most jurisdictions define the crime of prostitution as payment for sexual services involving a "person." For example, in Arizona, the crime of prostitution is defined as: "It is unlawful for a person to knowingly engage in prostitution." A.R.S. § 13-3214 (emphasis added). Since a sex robot is not a "person," it cannot engage in prostitution. Similarly, whereas it is illegal to operate or manage a house of prostitution, if no prostitution is occurring inside the building, because no human is offering sexual services, then there is presumably no criminal liability for the brothel owner or manager.

Another issue that may affect sex robot brothels though is zoning. Houston was the first city in the United States to open a robot "brothel" in 2018. The Houston City Council, in response to a citizen petition signed by thousands of people, banned the operation of the brothel before it even opened through an ordinance that banned sexual contact with "an anthropomorphic device or object" on commercial properties (Gersen, 2019).

Other cities may try to use similar strategies to keep sex robot brothels out of their communities. For example, the Barcelona sex robot brothel discussed above, which appears to be the first of its kind, now operates from a secret location because local residents "kicked up a storm" at its initial publicly disclosed location (Harper, 2017). Most residents and other businesses would be understandably opposed to having sex robot brothels operating in their neighborhoods. Such businesses would likely cause discomfort for passer-bys including children, may decrease property values, and may attract undesirable clienteles and other businesses. While anti-prostitution laws would provide legal leverage to block brothels with human workers from openly operating in many communities, those laws may not apply to sex robot brothels if the activities within do not qualify as prostitution. Thus, zoning restrictions may be the most effective legal tool for blocking sex robot brothels.

Moreover, the First Amendment prevents cities from discriminating against non-obscene sex-related businesses altogether. For example, in Schad v. Mount Ephraim (1981), the Supreme Court ruled that while city zoning may create adult zones or limit the placement of adult entertainment businesses within a community, the city may not zone them out completely or restrict them to small and highly inaccessible areas. Thus, while objections to sex robot brothels are likely and understandable, it is not clear whether communities will have viable long-term legal tools to prohibit such businesses from operating in their neighborhoods. 


\section{CONCLUSION}

Sex robots are not a common phenomenon at this time; very few people have encountered or interacted with such machines to date. However, sex robots have generated an enormous amount of interest and commentary in the public arena already (Bendel, 2021), supporting predictions that they will become a commonplace reality in the not too distant future. As David Levy has written, "[h]umans will fall in love with robots, humans will marry robots, and humans will have sex with robots, all as ... 'normal' extensions of our feelings of love and sexual desire for other humans" (Levy, 2007, p. 22).

The history of the U.S. legal response to non-traditional sexual objects or activities suggests that sex robots will be subject initially to restrictive and reactionary legal restrictions as they become more popular. Some states are likely to attempt to ban sex robots outright, appealing to politically popular puritanical sentiments, but such bans based on public morality are unlikely to succeed legally or politically in the longer term in most jurisdictions. More focused legal restrictions - based on more legitimate and practical apprehensions, are more likely to succeed. These include prohibitions of child sex robots in order to prevent more pedophilia, not recognizing robot-human marriage in order to sanctify the special human bonding that characterizes marriage, and blocking sex robot brothels using zoning or prostitution laws in order to prevent the deterioration of neighborhoods. Yet, each of these more limited prohibitions may run afoul of U.S. Constitutional restrictions and policy arguments for allowing such sex robot applications. Law students take note, there is likely to be much legal work ahead addressing the emerging phenomenon of love and sex with robots.

\section{REFERENCES}

Ashcroft v. Free Speech Coalition (2002). 535 U.S. 234-273. U.S. Supreme Court.

Balkin, J. (2020). What Obergefell v. Hodges Should Have Said. New Haven, CT: Yale University Press.

Barnes v. Glen Theatre, Inc. (1991). 501 U.S. 560-596. U.S. Supreme Court.

Bendel, O. (2021). Love dolls and sex robots in unproven and unexplored fields of application. Paladyn, Journal of Behavioral Robotics, 12(1), 1-12. doi:10.1515/pjbr-2021-0004.

Bowers v. Hardwick (1986) 478 U.S. 186-220. U.S. Supreme Court.

Brandenburg v. Ohio (1969). 395 U.S. 444. U.S. Supreme Court.

Campaign Against Porn Robots (undated). Retrieved from https://campaignagainstsexrobots.org/.

Chatterjee, B.B. (2017). Child sex dolls and robots: Exploring the legal challenges. The Conversation, Aug. 3, 2017. Retrieved from https://theconversation.com/child-sex-dolls-and-robots-exploring-thelegal-challenges-81912.

Cox, D. (2018). Would child sex robots stop pedophilia - or promote it?. NBC News, Jan. 4, 2018. Retrieved from https://www.nbcnews.com/mach/science/would-child-sex-robots-stop-pedophilia-orpromote-it-ncna834576.

Danaher, J. (2017a). Robotic rape and robotic child sexual abuse: Should they be criminalised? Criminal Law and Philosophy, 11, 71-95. doi:10.1007/s11572-014-9362-x.

Danaher, J. (2017b). Should we be thinking about robot sex. In J. Danaher and N. McArthur (Eds.), Robot Sex: Social and Ethical Implications (pp. 3-14). Cambridge, MA: The MIT Press. doi:10.7551/ mitpress/9780262036689.001.0001. 
Danaher, J., Earp, B. \& Sandberg, A. (2017). Should we campaign against sex robots? In J. Danaher and N. McArthur (Eds.), Robot Sex: Social and Ethical Implications (pp. 47-71). Cambridge, MA: The MIT Press. doi:10.7551/mitpress/9780262036689.001.0001.

Dearden, L. (2017). Man sentenced for importing childlike sex doll from Hong Kong. The Independent, Sept. 29, 2017. Retrieved from http://www.independent.co.uk/news/uk/crime/simon-glerumchild-sex-doll-guilty-sentence-jail-latest-court-trial-essex-hong-kong-indecent-obscene-a7973876.

html.

Devlin, K. (2018). Turned on: Science, Sex and Robots. London, UK: Bloomsbury Press.

Dickson, E.J. (2014). Could child sex robots "cure" pedophilia? The Daily Dot, July 16, 2014. Retrieved from https://www.dailydot.com/via/child-sex-robots-pedophilia/.

Elvin, S. (2020). Bodybuilder marries sex doll after two years of 'dating'. Metro, Dec. 1, 2020. Retrieved from https://metro.co.uk/2020/12/01/bodybuilder-marries-sex-doll-after-two-years-of-dating$13681356 /$.

Felton, J. (2018). US lawmakers approve CREEPER Act to ban child sex robots. IFLScience!, Jun. 15, 2018. Retrieved from https://www.iflscience.com/technology/us-lawmakers-approve-creeper-actto-ban-particularly-horrifying-sex-robots/.

Gersen, J.S. (2019). Sex lex machine: Intimacy and artificial intelligence. Columbia Law Review, 119, 1793-1809.

Goldberg, S. (2004). Morals-based justifications for lawmaking: Before and after Lawrence v. Texas. Minnesota Law Review, 88, 1233-1311.

Harper, P. (2017). Inside the Barcelona brothel where women have been replaced by silicone dolls so randy punters can fulfil fantasies they wouldn't dream of revealing to a human. The Sun (U.K.), Oct. 27, 2017. Retrieved from https://www.thesun.co.uk/news/4779261/inside-the-barcelona-brothelwhere-women-have-been-replaced-by-inflatable-dolls-so-randy-punters-can-fulfil-fantasies-theywouldnt-dream-of-revealing-to-a-human/.

Jecker, N.S. (2021). Nothing to be ashamed of: Sex robots for older adults with disabilities. Journal of Medical Ethics, 47(1), 26-32. doi:10.1136/medethics-2020-106645.

Kaplan, M. (2014). Sex-positive law. New York University Law Review, 89(1), 89-164.

Kleeman, J. (2020). Sex Robots and Vegan Meat. London, U.K.: Picador.

Lawrence v. Texas (2003). 539 U.S. 558-606. U.S. Supreme Court.

Levy, A.F. (2018). The "CREEPER Act" would be yet another unconstitutional law from Congress, Technology \& Marketing Law Blog, June 28, 2018. Retrieved from https:// blog.ericgoldman.org/archives/2018/06/the-creeper-act-would-be-yet-another-unconstitutionallaw-from-congress-guest-blog-post.htm\#: :text=The\%20CREEPER\%20Act\%20seeks\%20to, unconstitutional\%20under\%20the\%20First\%20Amendment.

Levy, D. (2007). Love and Sex with Robots: The Evolution of Human-Robot Relationships. New York, NY: HarperCollins.

Lockett, J. (2017). World's first brothel staffed entirely by robot sex workers now looking for investors to go global. The Sun. Jul. 30, 2017. Retrieved from https://www.thesun.co.uk/news/4131258/worldsfirst-brothel-staffed-entirely-by-robot-sex-workers-now-looking-for-investors-to-go-global/.

Loving v. Virginia (1967). 388 U.S. 1-12. U.S. Supreme Court. 
Lui, K. (2017). A U.K. judge has ruled that sex dolls resembling children are 'obscene'. Time, July 31, 2017. Retrieved from http://time.com/4881826/united-kingdom-child-sex-dolls-obscene/.

Maras, M.H. \& Shapiro, L. (2017). Child sex dolls and robots: More than just an uncanny valley. Journal of Internet Law, 3-21.

Marchant, G. (2015). Humans should be able to marry robots. Slate.com. Aug. 10, 2015. Retrieved from www.slate.com/articles/technology/future_tense/2015/08/humans_should_be_able_to_ marry_robots.html.

Miller v. California (1973). 413 U.S. 15-48. U.S. Supreme Court.

Montgomery Highway v. City of Hoover (2010). 45 So.3d 319-347. Supreme Court of Alabama.

Moosa, T. (2014). Robots and sex: Creepy or cool?. TheGuardian.Com, Apr. 7, 2014. Retrieved from https://www.theguardian.com/science/brain-flapping/2014/apr/07/robots-and-sex-creepy-or-cool.

Morin, R. (2016). Can child dolls keep pedophiles from offending? The Atlantic, Jan. 11, 2016. Retrieved from https://www.theatlantic.com/health/archive/2016/01/can-child-dolls-keep-pedophilesfrom-offending/423324/.

Obergefell v. Hodges (2015). 576 U.S. 644-742. U.S. Supreme Court.

Osborne, D.S. (2020). Personhood for synthetic beings: Legal parameters and consequences of the dawn of humanlike artificial intelligence. Santa Clara High Tech Law Journal, 37, 257-299.

Posner, R.A. (1992). Sex and Reason. Cambridge, MA: Harvard University Press.

Potter v. Murray City (1985). 760 F.2d 1064-1072. United States Court of Appeals, Tenth Circuit.

Reliable Consultants, Inc. v. Earle (2008). 517 F.3d 738-751. United States Court of Appeals, Fifth Circuit.

Revesz, R. (2017). Paedophiles 'could be prescribed child sex dolls' to prevent real attacks, says therapist. The Independent, Aug. 2, 2017. Retrieved from http://www.independent.co.uk/news/uk/ home-news/paedophiles-child-sex-dolls-prescription-stop-attacks-child-protection-stopso-therapistsa7872911.html.

Richardson, K. (2016). Sex robot matters: Slavery, the prostituted, and the rights of machines. IEEE Technology and Society Magazine, 35(2), 46-53. doi:10.1109/MTS.2016.2554421.

Roth v. United States (1957). 354 U.S. 476-514. United States Supreme Court.

Rubin, G.S. (2011). Thinking sex: Notes for a radical theory of the politics of sexuality. In G.S. Rubin (Ed.), Deviations: A Gayle Rubin Reader (pp. 137-181). Durham, NC: Duke University Press. doi:10. 2307/j.ctv11smmmj.9.

Rutkin, A. (2016). Could sex robots and virtual reality treat paedophilia? New Scientist, Aug. 2, 2016. Retrieved from https://www.newscientist.com/article/2099607-could-sex-robots-and-virtual-realitytreat-paedophilia/.

Ryznar, M. (2019). Robot love. Seton Hall Law Review, 49, 353-374.

Schad v. Mount Ephraim (1981). 452 U.S. 61-88. U.S. Supreme Court.

Shen, F. (2019). Sex robots are here, but laws aren't keeping up with the ethical and privacy issues they raise. The Conversation, Feb. 12, 2019. Retrieved from https://theconversation.com/sex-robotsare-here-but-laws-arent-keeping-up-with-the-ethical-and-privacy-issues-they-raise-109852.

Simmons, T.E. (2016). Sexbots; an obloquy. Wisconsin Law Review, 2016(1), 45-53. 
Stanley v. Georgia (1969). 394 U.S. 554-572. U.S. Supreme Court.

Strikwerda, L. (2017). Legal and moral implications of child sex robots. In J. Danaher and N. McArthur (Eds.), Robot Sex: Social and Ethical Implications (pp. 133-151). Cambridge, MA: The MIT Press.

Sunstein, C.R. (1986). Pornography and the first amendment. Duke Law Journal, 1986(4), 586-627. doi:10.2307/1372485.

Walter, N.J. (2020). You may kiss the AI: An analysis of whether rationales for legalizing some nontraditional marriages also justify legalizing human-robot marriage. Jurimetrics, 60, 353-380.

Williams v. Att'y Gen. of Ala (2004). 378 F.3d 1232-1260. United States Court of Appeals, Eleventh Circuit.

Williams v. Morgan (2007). 478 F.3d 1316-1324. United States Court of Appeals, Eleventh Circuit.

Wodda, A. \& Panfil, V.R. (2018). Insert sexy title here: Moving toward a sex-positive criminology. Feminist Criminology, 13(5), 583-608. doi:10.1177/1557085117693088.

Yeoman, I. \& Mars, M. (2012). Robots, men and sex tourism. Futures, 44, 365-371. doi:10.1016/j. futures.2011.11.004. 